\title{
Role of environmental seasonality in the turnover of a cetacean community in the southwestern Gulf of California
}

\author{
Mario A. Pardo ${ }^{1,5, *}$, Norman Silverberg ${ }^{1}$, Diane Gendron ${ }^{1}$, Emilio Beier ${ }^{2}$, \\ Daniel M. Palacios ${ }^{3,4}$
}

\footnotetext{
${ }^{1}$ Centro Interdisciplinario de Ciencias Marinas, Instituto Politécnico Nacional, La Paz, Baja California Sur 23096, Mexico

${ }^{2}$ Centro de Investigación Científica y de Educación Superior de Ensenada - Unidad La Paz, La Paz, Baja California Sur 23050, Mexico

${ }^{3}$ Cooperative Institute for Marine Ecosystems and Climate, Institute of Marine Sciences, Division of Physical and Biological Sciences, University of California, Santa Cruz, California 95060, USA

${ }^{4}$ NOAA, NMFS, Southwest Fisheries Science Center, Environmental Research Division, Pacific Grove, California 93950-2097, USA

${ }^{5}$ Present address: Posgrado en Ciencias del Mar y Limnología, Universidad Nacional Autónoma de México, Distrito Federal 04510, Mexico
}

\begin{abstract}
La Paz Bay is a distinct region within the Gulf of California whose rich cetacean community exhibits an intense annual overturn. We studied the environmental conditions that could drive this change over the course of a year. Cetacean biomass was estimated from monthly surveys, with concurrent collection of water-column measurements of temperature, salinity, nutrients, chlorophyll a (chl a), and biogenic matter fluxes. The water-column structure showed 3 major conditions: deep mixing during winter, stratified isopycnal shoaling in spring and early summer, and deep stratification during late summer and autumn. Chl $a$ and relative fluxes of biogenic silica and calcium carbonate indicated a seasonal succession of primary producers in response to the observed evolution of hydrography. During the periods of mixing and isopycnal shoaling, the bay provided suitable habitat for blue whales, bottlenose dolphins, and common dolphins, while fin whales, Bryde's whales, and short-finned pilot whales were numerically dominant during the period of stratification. To provide a regional context to the observed seasonality, we fitted temporal least-squares to an $11 \mathrm{yr}$ monthly time series of satellite-derived wind, sea surface temperature (SST), and chlorophyll concentration (CHL). Within the bay, the SST followed the annual monsoonal shift in the wind, whereas CHL showed a bi-modal pattern, with a main peak occurring under mixing conditions in winter and a second peak under isopycnal shoaling in spring/early summer. The regional fitting suggested that the latter period was driven by a localized intraseasonal phenomenon that could be responsible for the higher biological richness of the bay compared to the surrounding gulf.
\end{abstract}

KEY WORDS: Ecological succession - Seasonal variability - Nutrient supply - Stratification · Biogenic matter fluxes · Trophic levels · Marine hotspots

Resale or republication not permitted without written consent of the publisher

\section{INTRODUCTION}

Biological hotspots in the epipelagic zone have been described as areas where dynamic processes in the physical environment lead to enhanced productivity and aggregation of consumers relative to their surroundings (Palacios et al. 2006). In these areas, upwelling, mesoscale eddies, and fronts may act in concert with the local geomorphology to generate conditions that greatly promote the availability of 
prey for large fauna (e.g. Wingfield et al. 2011). Although these hotspots are often detectable through remote sensing of the ocean's surface, other areas that appear oligotrophic and devoid of dynamic features at the surface may also attract large feeding predators and even influence their migration patterns (e.g. Domeier et al. 2012). In such areas, the biological production maxima may be in the subsurface in the presence of a deep/sharp thermocline, underscoring the importance of measuring hydrographic and biological parameters, both at the surface and in the water column, for the characterization of biological hotspots.

The most productive areas of the Gulf of California (hereafter 'the gulf'; Fig. 1) are located along its east-

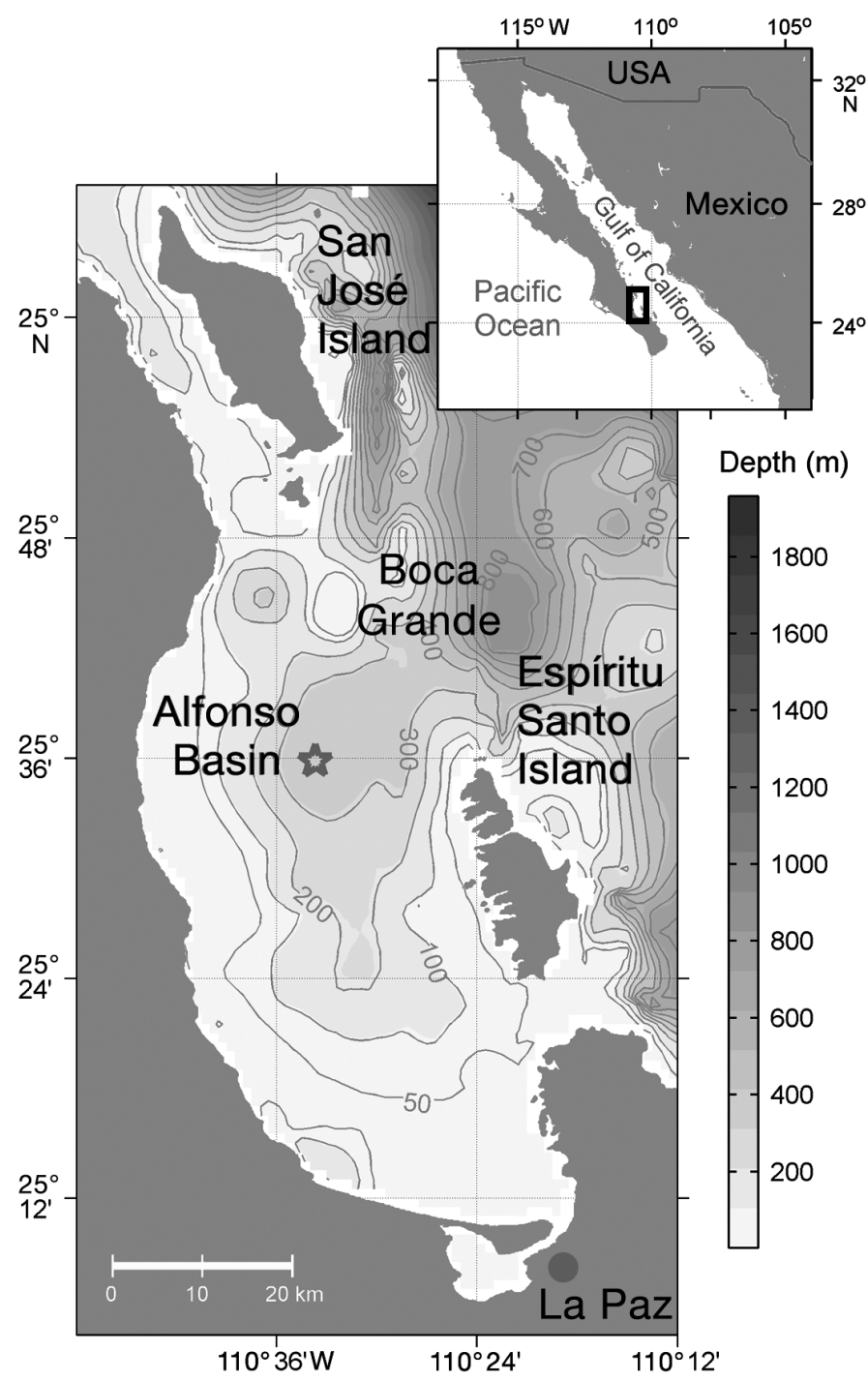

Fig. 1. La Paz Bay, in the southwestern Gulf of California (inset). The gray star in the main panel indicates the position of the oceanographic station and the site of the sediment trap in the deepest part of the bay $(\sim 410 \mathrm{~m})$ ern (continental) side and in the northern region due to winter upwelling and tidal mixing, respectively (Lluch-Cota 2000). The southwestern gulf (peninsular side) is comparatively less productive, except for La Paz Bay (hereafter 'the bay'), whose photosynthetic pigment concentrations remain high yearround compared to its surroundings, constituting an isolated spot of high phytoplankton biomass (Santamaria-del-Angel et al. 1994, Luch-Cota \& TenizaGuillén 2000, Kahru et al. 2004). The bay sustains a diverse megafauna that includes at least 16 cetacean species of temperate, tropical, and subtropical affinities (Flores-Ramírez et al. 1996, Salvadeo et al. 2009). It also hosts a growing colony of California sea lions Zalophus californianus (Szteren et al. 2006) and is visited by whale sharks Rhincodon typus and spinetail devil rays Mobula japanica, which arrive in winter, spring, and early summer to feed on zooplankton (Clark \& Nelson 1997, Ketchum-Mejía 2003, Croll et al. 2012). The rich cetacean community exhibits a strong annual overturn, with migratory species such as blue whales Balaenoptera musculus and humpback whales Megaptera novaeangliae occurring in winter and spring, whereas species with more tropical affinities, like Bryde's whales Balaenoptera edeni, bottlenose dolphins Tursiops truncatus, and short-finned pilot whales Globicephala macrorhynchus, occur mostly during the summer and autumn. Fin whales Balaenoptera physalus are resident in the gulf and, together with the common dolphins Delphinus spp. occur year-round (Flores-Ramírez et al. 1996, Salvadeo et al. 2009). The hydrographic conditions that support this cetacean diversity and underlie the species' replacement have not been studied.

In the present study, we posit that seasonal forcing of oceanographic conditions in the bay, including surface mixing driven by northwesterly winds in winter (Badan-Dangon et al. 1991) and cyclonic circulation in summer (Monreal-Gómez et al. 2001, Sánchez-Velasco et al. 2006), lead to enhanced nutrient supply to the base of the food web, attracting low trophic level prey for planktivorous and piscivorous cetaceans. Warmer conditions in summer would, in turn, be favorable for the aggregation of higher trophic level prey looking for a suitable habitat to spawn near the coast (e.g. Staaf et al. 2008), attracting teutophagous cetaceans. To assess the specific hydrographic and biological conditions underlying species' replacement in the cetacean community of the bay, we make use of water-column data collected as part of a multidisciplinary time-series investigation, aimed at examining monthly changes in physical structure, nutrient and chlorophyll a (chl a) con- 
centrations, vertical fluxes of biogenic matter, and cetacean biomasses over the course of a year. The results are put in a regional context (i.e. the southwestern gulf) using time series of remotely sensed (satellite) measurements of surface wind, temperature (SST), and chlorophyll concentration (CHL).

Although direct measurements of the prey field would have probably enhanced our understanding of the relationships between cetaceans and the dynamics of their physical habitat in the bay, collection of such data was not possible due to logistical and financial constraints. Indeed, quantitative and comprehensive assessments of the intermediate trophic levels in the southwestern gulf are lacking. However, considering that most cetacean species must constantly search for food due to their high energetic needs (Trites et al. 1997, Barlow et al. 2008), we interpret their occurrence in the bay, at least in part, as a response to the prey availability, which is in turn aggregated by suitable physical and biological mechanisms. Further, the evolutionary and ecological adaptations of cetaceans to exploit specific types of prey, such as zooplankton, small pelagic fish, or squid (Pauly et al. 1998), facilitate such interpretation. This argument has been widely used to characterize cetacean habitats (e.g. Au \& Perryman 1985, Hamazaki 2002, Doniol-Valcroze et al. 2007, Praca et al. 2009) as well as to model cetacean abundance as a function of predominant environmental conditions (e.g. Becker et al. 2010, 2012, Gerrodette \& Eguchi 2011, Forney et al. 2012), even when there is no direct measurement of the potential prey.

\section{MATERIALS AND METHODS}

\section{Study area}

La Paz Bay is the largest and deepest embayment in the Gulf of California (Fig. 1), with an area of $\sim 2160 \mathrm{~km}^{2}$ and a maximum depth of $\sim 410 \mathrm{~m}$. Water exchange with the surrounding gulf occurs mainly through the northern channel, called Boca Grande (Salinas-González et al. 2003, Obeso-Nieblas et al. 2004). The bay lies within a tropical-subtropical transition zone that seasonally alternates between 2 welldefined periods as a result of the monsoonal regime that dominates the entire gulf. The temperate season, from November to April (winter to spring), is dominated by strong northwesterly winds that enhance evaporation and increase the surface salinity, which induces deep vertical convection (i.e. sinking). More moderate southwesterly winds blow during the warm season, from May to October (summer to autumn). During this period, the water column receives the influence of tropical waters, the thermocline deepens, and the upper layer stratifies (Badan-Dangon et al. 1991, Adams \& Comrie 1997, Bordoni et al. 2004).

\section{Hydrographic and biological conditions}

The changes in the physical structure of the water column and their influence on the base of the food web, through nutrient supply, help us to identify the predominant ecological conditions that attract different cetacean species at different times of the year. A number of physical, chemical, and biological variables were measured at an oceanographic station located over the deepest part of the bay $(\sim 410 \mathrm{~m}$; Fig. 1). Between 17 February 2007 and 18 February 2008, 13 CTD profiles were taken to depths ranging from 50 to $340 \mathrm{~m}$. Temperature, salinity, and density data were standardized to $1 \mathrm{~m}$ depth means. From these values, we computed the Brunt-Väisälä frequency (cycles $\mathrm{h}^{-1}$; also known as buoyancy frequency), a measure of the degree of stratification (Wahl \& Teague 1983). The depth of maximum buoyancy frequency in a profile corresponds to the depth of the pycnocline. At the same site, 13 profiles of Niskin-bottle samples were taken at discrete depths according to 6 levels of light penetration $(0.1,1,10$, 33,55 , and $100 \%$ ) estimated from Secchi disc measurements following the Beer-Bourguer-Lambert law (Walker 1982, Bustillos-Guzmán \& Lechuga-Devéze 1989). Concentrations of dissolved silica $\left(\mathrm{H}_{2} \mathrm{SiO}_{4}\right)$, phosphate $\left(\mathrm{PO}_{4}^{-3}\right)$, and total dissolved inorganic nitrogen $\left(\mathrm{NO}_{2}{ }^{-}+\mathrm{NO}_{3}{ }^{-}+\mathrm{NH}_{4}{ }^{-}\right)$were measured from these samples (Strickland \& Parsons 1972), as well as the concentration of chl a (Ritchie 2008). Since measurements were taken at different times and in some cases different depth levels, we performed an objective interpolation of these variables using a Gaussian weighting function (Jalickee \& Hamilton 1977, Boyer et al. 2005) with $30 \mathrm{~d}$ horizontal and $1 \mathrm{~m}$ vertical scales to represent the temporal evolution. All data were truncated below $100 \mathrm{~m}$ depth since preliminary evaluation of the results showed that most of the variability was concentrated above that level.

\section{Biogenic matter fluxes}

The sinking particulate matter is indicative of the nature of biogenic components and thus the ecological succession taking place in the upper layers 
(Bishop 1988, Silver \& Gowing 1991, Silverberg et al. 2006), which could trigger the incursion of different cetacean species according to their feeding requirements. We analyzed samples from a Technicap ${ }^{\circledR}$ PPS $3 / 3$ trap of $0.125 \mathrm{~m}^{2}$ aperture, which was anchored and suspended at $\sim 310 \mathrm{~m}$ depth at the same site as the oceanographic measurements (Fig. 1). The sinking matter was collected in separate bottles during 7 to $15 \mathrm{~d}$ periods each and then fixed with a preservative solution of $4 \%$ buffered formaldehyde saturated with sodium tetraborate. The total mass flux, in $\mathrm{g} \mathrm{m}^{-2} \mathrm{~d}^{-1}$, was estimated from 4 sub-samples, which were centrifuged for $25 \mathrm{~min}$ at $3000 \mathrm{rpm}(\sim 1600 \times g)$, decanted, and washed with distilled water. The collected material was weighed after a $72 \mathrm{~h}$ drying
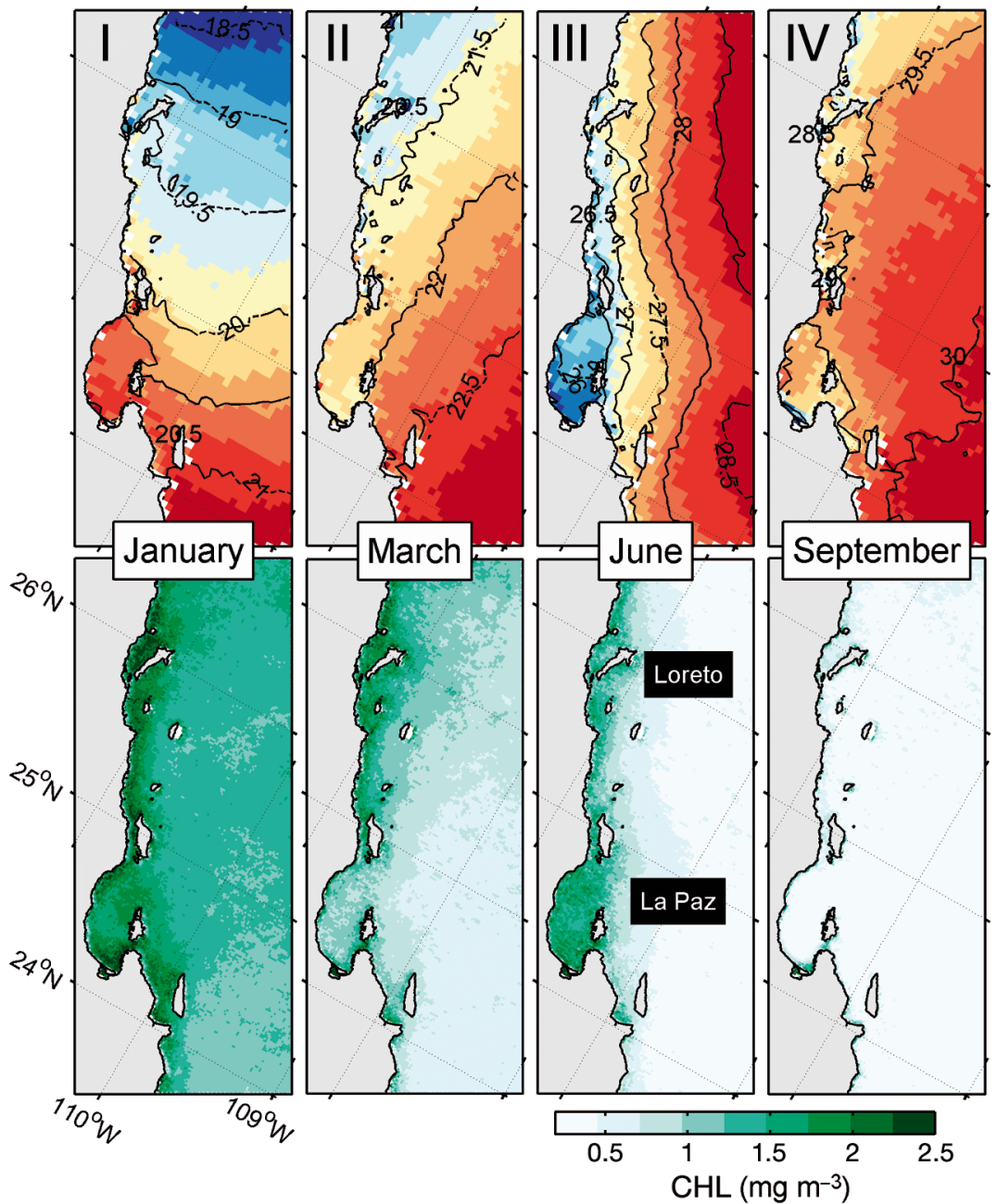

Fig. 2. Spatial representation of the 11 yr seasonal least-squares fits of sea surface temperature (SST; upper panels; in a variable color scale to highlight spatial gradients) and chlorophyll concentration (CHL; lower panels; same color scale among panels) for the southwestern Gulf of California. The periods shown were chosen following the maximum and minimum CHL values of the seasonal least-squares fit within La Paz Bay, which are denoted here and in Fig. 7 as I, II, III, and IV period at $\sim 50^{\circ} \mathrm{C}$. The lithogenic fraction of the total flux was subtracted since our interest was only related to the biological processes. From the total biogenic fractions, we analyzed the proportions of biogenic silica, or opal $\left(\mathrm{SiO}_{2} \cdot n \mathrm{H}_{2} \mathrm{O}\right)$, and calcium carbonate $\left(\mathrm{CaCO}_{3}\right)$.

\section{Local and regional seasonality}

Because of their great mobility, the incursions of different cetacean species into the bay could be the result of both local and/or regional conditions. Therefore, it was important to address the larger spatial context in which the hydrographic and biological conditions within the bay occur. Also, since the small sample sizes yielded by the present study (14 monthly data points) prevented us from quantitatively correlating cetacean densities to the monthly evolution of the water column within the bay, it was important to compare those conditions to longer time series of surface variables and put them in the spatial context of the southwestern gulf. We therefore characterized the seasonality of the entire region, from north of Loreto Bay to south of La Paz Bay (Fig. 2), using an 11 yr time series of remotely sensed SST and CHL as proxies for the physical and biological environment. The monthly CHL data came from the Sea-viewing Wide Field-of-view Sensor (SeaWiFS) aboard the satellite Orbview-2 (O'Reilly et al. 1998, 2000, Hooker \& McClain 2000), with a pixel resolution of $1.39 \mathrm{~km}$. The monthly SST data came from the Advanced Very High Resolution Radiometer (AVHRR) aboard NOAA satellites (Program Pathfinder 5.0; Walton et al. 1998, Casey \& Cornillon 1999, Kilpatrick et al. 2001), with a spatial resolution of $4.89 \mathrm{~km}$. Additionally, we used the monthly wind velocity data from the SeaWinds sensor aboard the NASA satellite QuikSCAT (Freilich 2000). Due to the coarser spatial resolution of this product (13.9 $\mathrm{km}$ ), only the measurement point closest to the bay was used to compute the local seasonality since the other available nearby points were on land or too far from the bay. All remotely sensed vari- 
ables were obtained through the Environmental Research Division's Data Access Program of NOAA, NMFS, Southwest Fisheries Science Center (http:// coastwatch.pfeg.noaa.gov/erddap/index.html). A spatially explicit characterization of the seasonal cycle of the southwestern gulf (Fig. 2) was done by fitting temporal least-squares with annual and semi-annual harmonics (Emery \& Thomson 1998, Ripa 2002) to the remotely sensed variables. Within the polygon of the bay (see map in Fig. 3), the temporal behavior of each variable was calculated using the same analyses, applied to the mean of all monthly values. The periods of maxima and minima resulting from the local (i.e. within the bay) CHL seasonal analysis were chosen to portray the results of the regional (i.e. southwestern gulf) analysis of SST and CHL (Fig. 2).

\section{Cetacean population density}

We conducted monthly visual surveys within the bay over a systematic zig-zag arrangement of transects (Fig. 3) aboard the $28 \mathrm{ft}$ (8.5 m) RV 'CICIMAR $\mathrm{XV}^{\prime}$ at $\sim 18 \mathrm{~km} \mathrm{~h}^{-1}$ between 6 February 2007 and 23 March 2008. Two trained observers simultaneously searched for cetaceans with the aid of $7 \times 50$ handheld binoculars (Fujinon ${ }^{\circledR}$ FMTRC-SX) equipped with compass and vertical reticles, independently covering both sides of the transect line, from the front of the vessel to an angle of $90^{\circ}$. A team of 4 observers rotated every $40 \mathrm{~min}$. Observations were made from a platform at $5.09 \mathrm{~m}$ effective visual height. The perpendicular distance $(x)$ from the transect line to the sighting was calculated following Lerczak \& Hobbs (1998). The animals were approached to confirm species identification only when they were within $\sim 1.5 \mathrm{~km}$ of the transect line (i.e. closing mode technique; Dawson et al. 2008). Most of the large species were easily identified beyond this distance, whereas
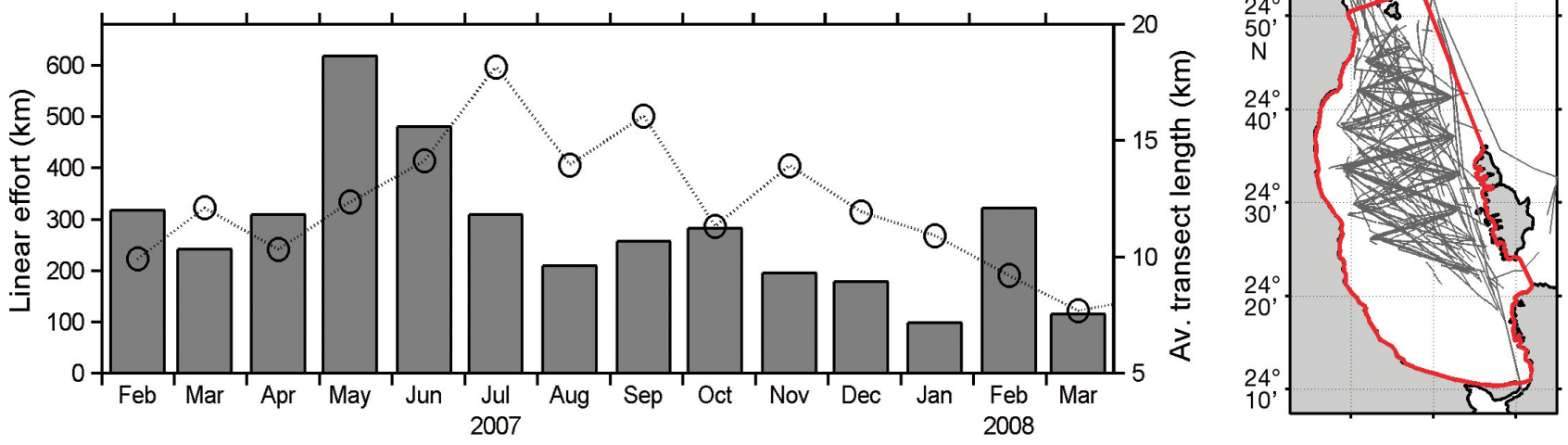

Fig. 3. Total survey effort by month (bars) and the average length of transects in each month (dotted line with circles). Map some dolphin schools remained unidentified as well as some whales recorded too far from the transect line. Search effort was suspended during the approach and the time spent with the animals as well as when the Beaufort sea-state was higher than 3.

Monthly population densities (individuals $\mathrm{km}^{-2}$ ) were estimated using distance sampling line-transect techniques (Buckland et al. 2001) by modeling a detection probability function $g(x)$, based on the distribution of all perpendicular distances from the transect line to the groups sighted of each species. Since the cetacean surveys have continued within and outside the bay after the completion of the present study, we used all of the perpendicular distances available through April 2012 to improve the modeling of the detection functions (Fig. 4). We established a priori truncation points $(w)$ based on the frequency distribution of distances. The effective half-strip width $(\mu)$ was estimated from the detection function to convert the linear effort into an effectively sampled area (Thomas et al. 2002). Several mathematical functions (uniform, half-normal, and hazard-rate) and expansion series (cosine, sine, simple polynomial, and hermit polynomial) were tested, and Akaike's information criterion (Burnham \& Anderson 2002) was used to choose the best fit (Table 1). This function, evaluated at zero perpendicular distance, represents the detection probability $\hat{f}(0)$. Mean group sizes $\hat{E}(\mathrm{~s})$ were estimated for the odontocetes and the fin whale, whereas for the blue and the Bryde's whale, the few sightings of $>1$ animal were split into individual detections to avoid the increase of the variance due to the indeterminacy of the expected group size. For all species, we assumed that all animals located directly on the track-line were detected and counted (i.e. $g(0)=1$ ). Finally, $\hat{f}(0)$ was used, together with the number of counted groups (n) and the total transect

\footnotetext{
shows the polygon of La Paz Bay (red line) and the transect track lines (dark grey lines)
} 


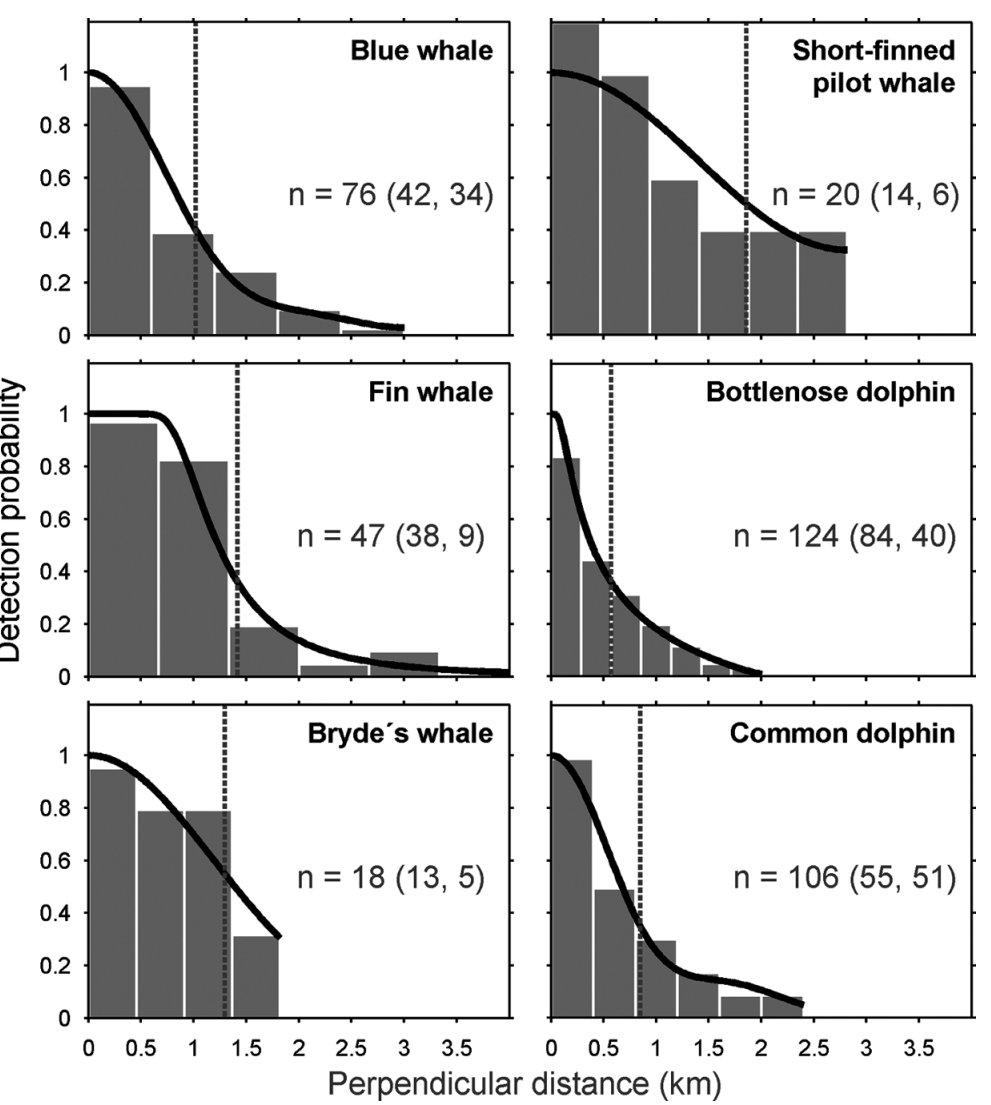

Fig. 4. Detection probability function $(g(x)$; black line), estimated from the distribution of perpendicular sighting distances (gray bars). The estimated effective half-strip width $(\mu)$ is shown as a dashed vertical line. The total number of distances used (n) is presented, specifying the number of distances from the study period and area (first value within parentheses) and the distances taken from subsequent years and/or areas aboard the same platform (second value within the parentheses)

length $(L)$, to estimate a point density value $(\ddot{D})$ for each month (Thomas et al. 2002). The variance $\widehat{\operatorname{var}}(D)$ and the lower and upper limits of the $95 \%$ confidence intervals $(D / C, D \cdot C)$ were estimated by a 999 iteration bootstrap analysis of samples (i.e. transects) at each stratum (i.e. month). For the lessfrequent species, we only calculated the encounter rate of groups as the number of sightings recorded in the total linear effort in each survey. Although both the short-beaked common dolphin Delphinus delphis and the long-beaked common dolphin Delphinus capensis occur in the Gulf of California, we treated them at the genus level, given the difficulty in identifying them to species level in most sightings.

\section{Cetacean biomass}

The population density estimates (individuals $\mathrm{km}^{-2}$ ) were converted into values of biomass $\left(\mathrm{t} \mathrm{km}^{-2}\right)$ to make the species comparable. This was done by multiplying the estimated density by the mean species-specific body mass values previously reported for the California Current (Barlow et al. 2008 and references therein). These values come from both direct measurements and regression models of body mass as a function of the mean body length (Table 2).

\section{RESULTS}

\section{Hydrographic and biological conditions}

Temperature dominated the density structure in the water column (Fig. 5). Cold water $\left(<18^{\circ} \mathrm{C}\right)$ occurred throughout the first $100 \mathrm{~m}$ during the winter (February 2007 and January to February 2008). During March 2007, the upper $75 \mathrm{~m}$ were above $20^{\circ} \mathrm{C}$. From April to July, a doming of the isotherms took place, and water below $17^{\circ} \mathrm{C}$ penetrated the surface layer up to $10 \mathrm{~m}$. From June to November, the upper $25 \mathrm{~m}$ warmed above $25^{\circ} \mathrm{C}$. December was a transition period in which the temperature in the upper $55 \mathrm{~m}$ cooled below $21^{\circ} \mathrm{C}$. The Brunt-Väisälä frequency (Fig. 6a) showed 3 major conditions over the year, defined by the depth and degree of stratification. High values indicate a strong stratification, whereas low values mean strong mixing. The low buoyancy contours in February to March 2007 and January to February 2008 indicated deep mixing in the upper water column. During these winter periods, the pycnocline (i.e. the maximum buoyancy frequency along the profile) deepened to at least $100 \mathrm{~m}$. Then, during the spring and early summer, the buoyancies in the upper $25 \mathrm{~m}$ marked a period of isopycnal shoaling, when the pycnocline almost reached the surface. This doming of isopycnals lasted $4 \mathrm{mo}$, until early August, and it was followed by a thickening of the stratified upper layer in the late summer and autumn, marking conditions of deep stratification, with the pycnocline around $40 \mathrm{~m}$ depth. These conditions prevailed until December 2007, when a mixed period developed again.

For nutrients, we only show the concentration $(\mu \mathrm{M})$ of the sum of all components (Fig. 6b) since concentrations of dissolved silica, phosphate, and total dissolved inorganic nitrogen followed similar patterns over the course of the year. Relatively high concen- 


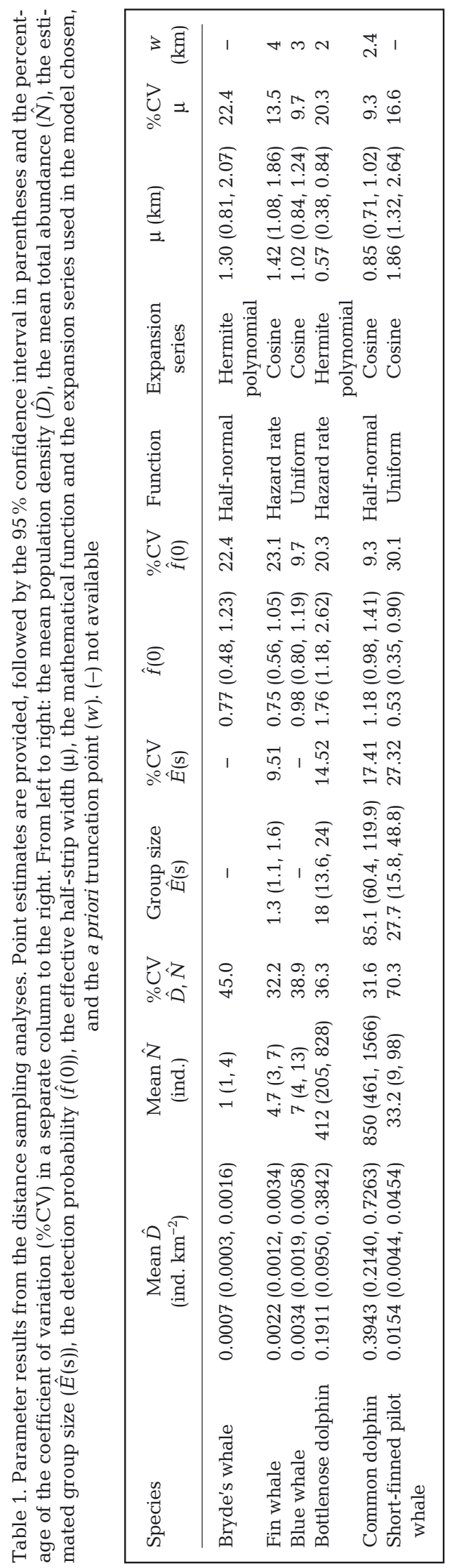

trations of nutrients were found in the water column during the mixing conditions in the winter, but there was an evident depletion in the upper $50 \mathrm{~m}$ during February and March 2007. The pycnocline shoaling of the spring and early summer brought higher subsurface concentrations of nutrients to just below the thermocline, reaching up to $50 \mu \mathrm{M}$ in the top $100 \mathrm{~m}$. The surface and sub-surface concentration of nutrients decreased in the late summer and autumn.

Two different types of chl a concentration peaks occurred (Fig. 6c): during the winters of 2007 and 2008, high concentrations $\left(\sim 1.5 \mathrm{mg} \mathrm{m}^{-3}\right)$ were recorded above the pycnocline in the upper $40 \mathrm{~m}$ and upper $70 \mathrm{~m}$, respectively, whereas under conditions of shallow stratification, higher values $\left(\sim 2.5 \mathrm{mg} \mathrm{m}^{-3}\right)$ occurred as 2 sub-surface maxima in May and August, just below the pycnocline. Low chl a concentrations $\left(<0.5 \mathrm{mg} \mathrm{m}^{-3}\right)$ in the upper $100 \mathrm{~m}$ characterized the deep stratified conditions of the late summer (September to November). Biogenic silica contributed strongly to the total biogenic flux from winter to early summer, reaching a maximum of $60 \%$ in April 2007, whereas carbonate $\left(\mathrm{CaCO}_{3}\right)$ components dominated during the late summer and autumn, reaching $48 \%$ in October 2007 (Fig. 6d). The 2 components showed completely opposite seasonal patterns. A Pearson's test resulted in a correlation of $-0.7032(\mathrm{p}=0.002,95 \% \mathrm{CI}=[-0.8324,-0.5016], \mathrm{n}=$ 40 , effective degrees of freedom $\left(\mathrm{N}_{\mathrm{eff}}\right)=17$ following Davis 1978).

\section{Local and regional seasonality}

The seasonal cycle of surface wind, SST, and CHL showed different patterns within the bay. The wind followed the monsoonal cycle (Fig. 7a). The annual pattern of the temperature was unimodal, with a

Table 2. Values of body mass used to standardize the density estimates of the dominant species (after Barlow et al. 2008)

\begin{tabular}{|llc|}
\hline Species & Common name & $\begin{array}{c}\text { Mean body } \\
\text { mass (t) }\end{array}$ \\
\hline Mysticetes & & \\
Balaenoptera edeni & Bryde's whale & 16.477 \\
Balaenoptera physalus & Fin whale & 42.150 \\
$\begin{array}{l}\text { Balaenoptera musculus } \\
\text { Odontocetes }\end{array}$ & Blue whale & 57.230 \\
$\begin{array}{l}\text { Tursiops truncatus } \\
\text { Delphinus spp. }\end{array}$ & $\begin{array}{c}\text { Bottlenose dolphin } \\
\text { (offshore) }\end{array}$ & 0.188 \\
$\begin{array}{l}\text { Globicephala } \\
\text { macrorhynchus }\end{array}$ & $\begin{array}{c}\text { Common dolphins } \\
\text { Short-finned pilot }\end{array}$ & 0.080 \\
whale & 0.608 \\
\hline
\end{tabular}




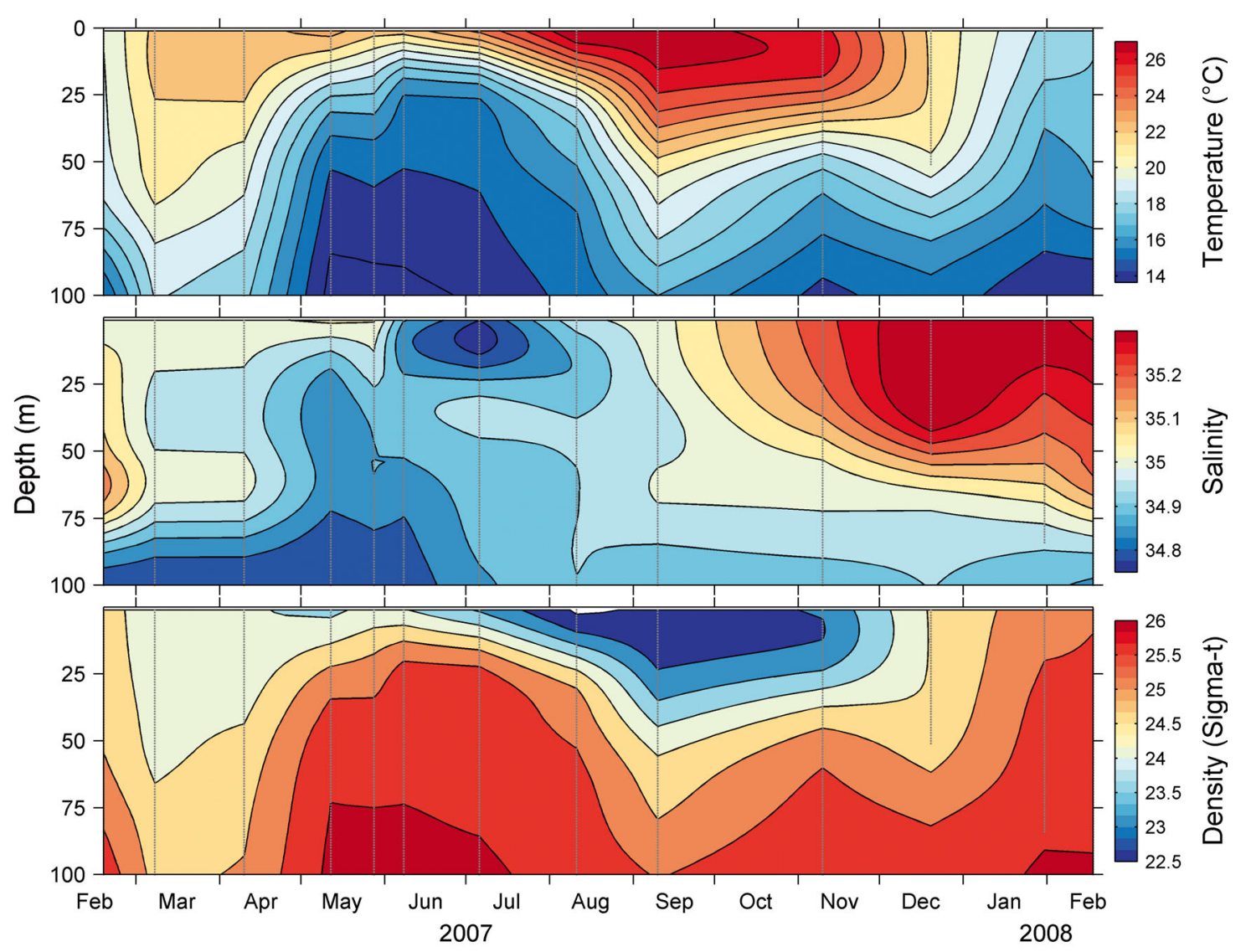

Fig. 5. Monthly progression of hydrographic variables in La Paz Bay (from objective interpolations using a Gaussian weighting function). Each cast is shown as a vertical gray line

maximum in September and a minimum in January (Fig. 7b). In contrast, the CHL pattern was bimodal, with a maximum in January (I in Fig. 7c), a decrease in March (II in Fig. 7C), a secondary peak at the end of May (III in Fig. 7c), and the main minimum in September (IV in Fig. $7 \mathrm{c}$ ). Note that, except for the very warm September period when CHL values were lowest throughout the region (IV in Fig. 2), the values within the bay tended to be higher than in the gulf waters offshore. These values were similar to adjacent coastal areas in January (I in Fig. 2), lower than offshore and coastal areas in March (II in Fig. 2), and significantly higher than anywhere else in June (III in Fig. 2). The least-squares SST values within the bay were slightly warmer than elsewhere in January and cooler the rest of the year, considerably so in June.

\section{Cetacean population density}

Altogether, the effective search effort within the bay during the 14 mo totaled $3937 \mathrm{~km}$ (mean $\pm \mathrm{SD}=$ $281 \pm 137$ km; Fig. 3). Four mysticete and 6 odontocete species were identified from 276 sightings. The blue whale, fin whale, Bryde's whale, common dolphin, bottlenose dolphin, and short-finned pilot whale were the most frequent species observed (Table 1, Fig. 8). The humpback whale, sperm whale Physeter macrocephalus, dwarf sperm whale Kogia sima, and killer whale Orcinus orca were only sporadically recorded (Fig. 8). Differences in the estimated effective half-strip widths ( $\mu$ in Fig. 4 ) between species typically suggest interspecific variations that determine their detectability, such as their body sizes, grouping behavior, and/or level of surface activity (e.g. Barlow \& Forney 2007, Williams \& Thomas 2007). Mysticetes in general had the widest effective halfstrip widths due to their larger body sizes and taller blows. Among the odontocetes, the short-finned pilot whales had the largest effective half-strip width, probably because of the combination of large groups and large body sizes. They were followed by the common dolphins, whose high level of surface activity and tendency to aggregate in very large groups make them detectable at large distances. Bottlenose dolphins had the shortest distance range, which could be attributed to their tendency to approach the vessel and to the small group sizes recorded within the bay. 


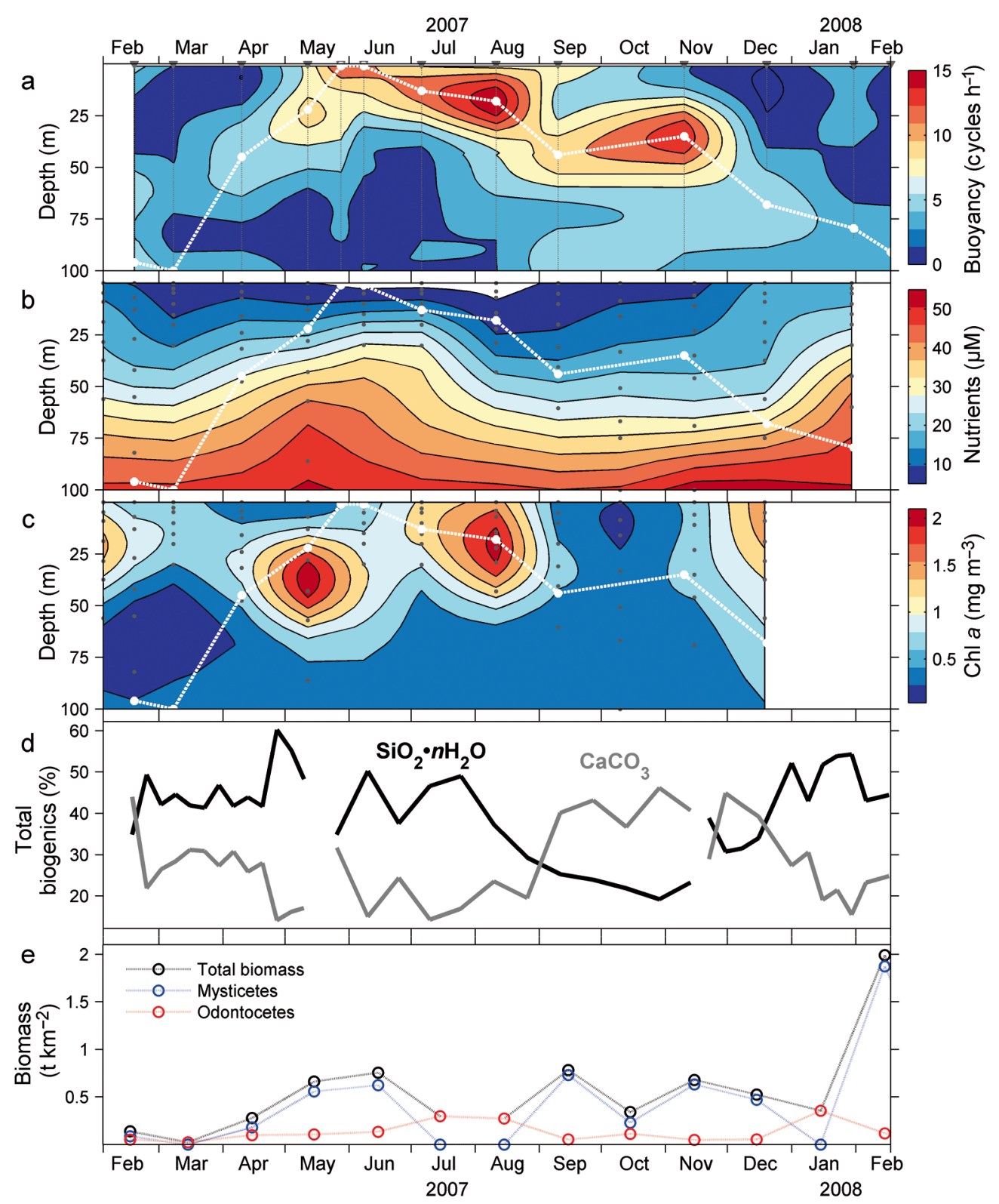

Fig. 6. Physical and biological context underlying variations in cetacean biomass in La Paz Bay. (a) Buoyancy frequency, with the dashed white line representing the depth of the pycnocline (i.e. maximum buoyancy frequency at each profile). Gray dots show the depth of the Niskin-bottle samples for (b) nutrients and (c) chl a. (d) The contributions of biogenic silica $\left(\mathrm{SiO}_{2} \cdot \mathrm{nH}_{2} \mathrm{O}\right.$ ) and calcium carbonate $\left(\mathrm{CaCO}_{3}\right)$ to the total biogenic sinking matter, shown as 7 to $15 \mathrm{~d}$ absolute values. (e) Monthly cetacean biomass

\section{Cetacean biomass}

Overall cetacean biomass was dominated by the mysticetes and displayed 3 major peaks (Figs. 6e \& 8). The first occurred in spring, from May to June 2007, the second covered late summer and autumn (September to December), and the third and highest was in February 2008 (Fig. 6e). The odontocetes showed an opposite pattern from the mysticetes (Fig. 6e): They increased in biomass when mysticetes de- creased, showing 2 main peaks during July to August 2007 and in January 2008. The first mysticete peak of the spring $\left(0.62 \mathrm{t} \mathrm{km}^{-2}\right)$ resulted from the co-occurrence of the 3 most frequent species but was dominated by the blue whale (Fig. 8). In contrast, the peaks of the late summer and autumn $(0.73$ and $0.63 \mathrm{t}$ $\mathrm{km}^{-2}$, respectively) were dominated by the fin whale in the absence of the blue whale and the occurrence of the Bryde's whale, the latter always in low biomasses. Finally, the highest peak of mysticete bio- 


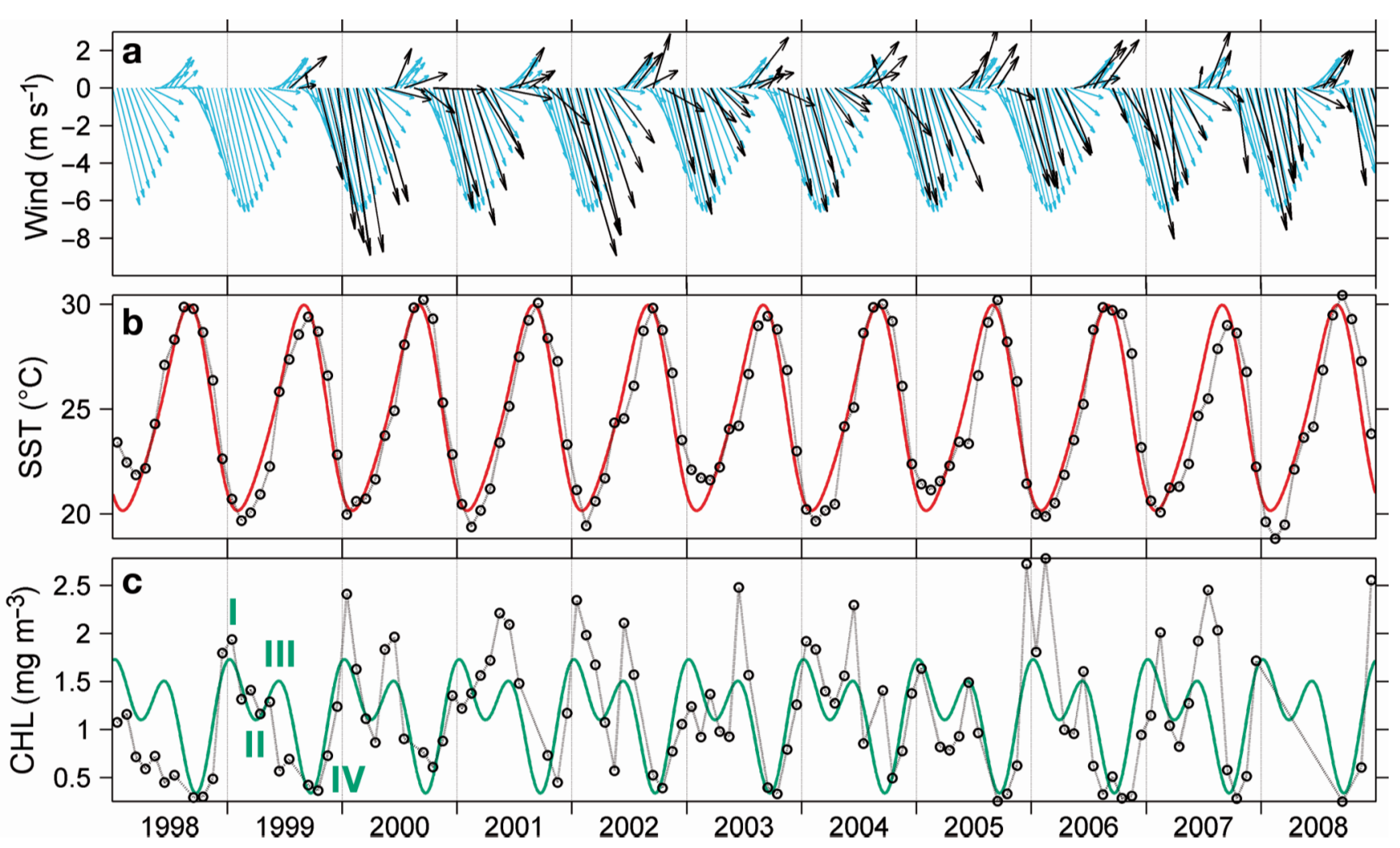

Fig. 7. Seasonal pattern of wind, sea surface temperature (SST), and chlorophyll concentration (CHL) in La Paz Bay. The black arrows (a) and circles $(\mathrm{b}, \mathrm{c})$ represent the original monthly values. The seasonal fits of wind, SST, and CHL are drawn as blue arrows and red and green lines, respectively. The seasonally adjusted maxima and minima of CHL are labeled as I, II, III, and IV, which are the periods chosen to portrait the regional (i.e. the entire southwestern gulf) spatial-temporal fit of SST and CHL in Fig. 2

mass $\left(1.87 \mathrm{t} \mathrm{km}^{-2}\right)$ occurred during February 2008 and was also dominated by blue whales but in the presence of fin and Bryde's whales (Fig. 8). The first peak of odontocetes biomass ( 0.30 to $0.27 \mathrm{t} \mathrm{km}^{-2}$, July to August 2007) resulted from the increase in bottlenose dolphins and from the incursion of short-finned pilot whales, whereas the second peak $\left(0.35 \mathrm{t} \mathrm{km}^{-2}\right)$ was dominated by the common dolphins, with a moderate increase of bottlenose dolphins, which dominated the odontocete biomass during the rest of the year (Fig. 8).

\section{DISCUSSION}

The strong mixing in winter and the isopycnal shoaling in spring and early summer produced peaks in surface and subsurface chl a concentrations, respectively (Fig. 6c). The high proportion of opal in the biogenic sinking matter (Fig. 6d) suggests that these peaks were dominated by diatoms and silicoflagellates, whose blooms result from the input of new nutrients into the euphotic zone (Egge \& Aksnes
1992) and typically favor the aggregation of krill and planktivorous fish (Kudela et al. 2008). Silicoflagellates and diatoms have been previously found as dominant among the micro- and nano-phytoplankton within the bay (Verdugo-Díaz 2003). The former have been associated with peaks of primary production in winter and early summer (Villegas-Aguilera 2009, Martínez-López et al. 2012) and are abundant in the siliceous fraction of the sediment trap samples (Álvarez-Gómez 2010). These $2 \mathrm{chl}$ a peaks observed in the water column are in agreement with the remotely sensed CHL peaks of the seasonal analysis derived from the $11 \mathrm{yr}$ least-squares regression (Fig. 7). This constitutes evidence that the isopycnal shoaling within the bay and its influence on phytoplankton is not a phenomenon particular only to the sampled year cycle but a recurring intraseasonal event of local nature. While the first CHL peak within the bay corresponds to a general pattern of high CHL values along the entire region of the southwestern gulf (I in Fig. 2), especially near the coast, the second corresponds to a local phenomenon, in which the bay gets colder and CHL-richer than the surrounding 

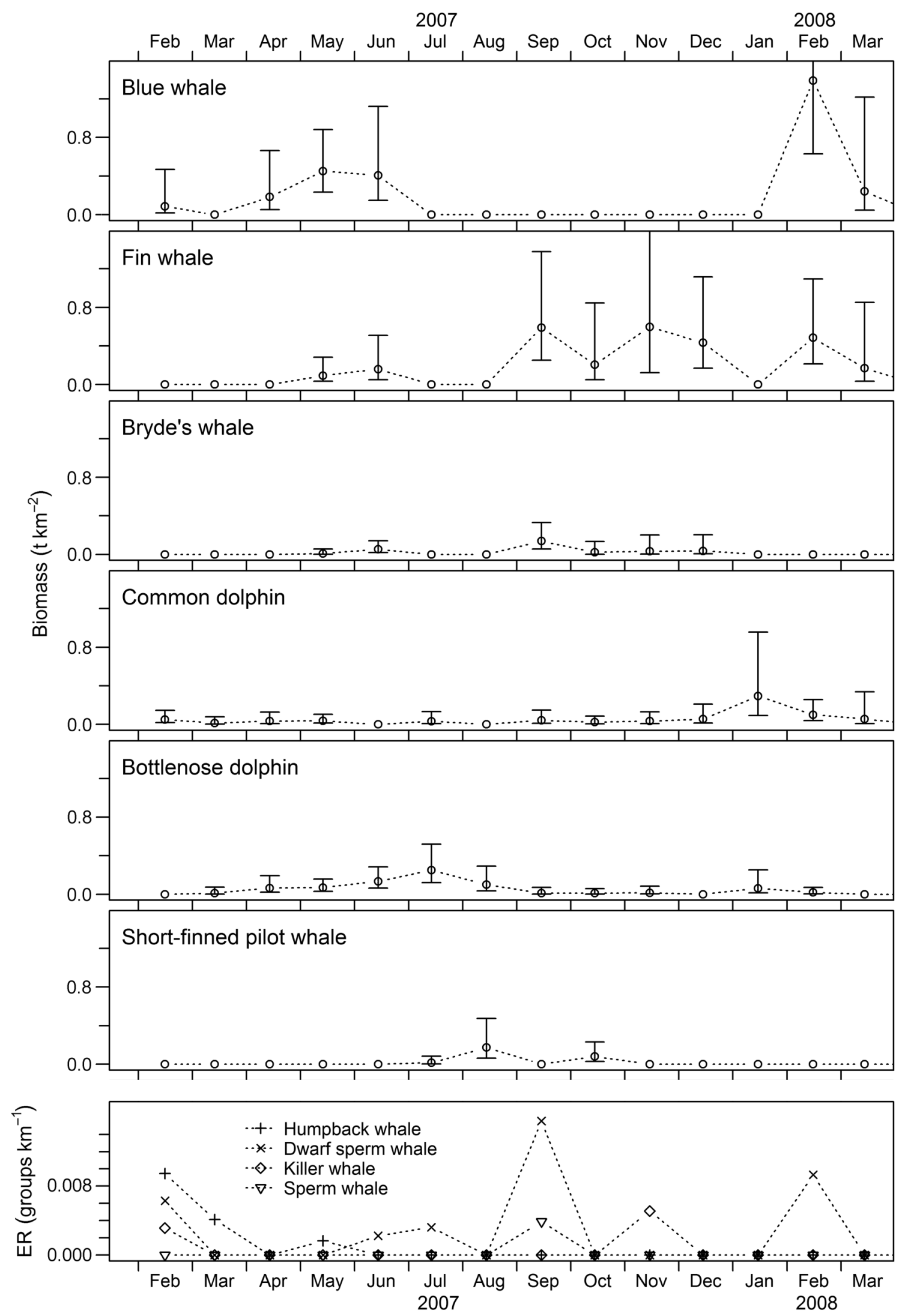

Fig. 8. Monthly estimates of cetacean biomass $( \pm 95 \%$ confidence intervals) for the dominant species and encounter rates (ER) for the less-frequent species (bottom panel) 
gulf (III in Fig. 2). Note that even when the cold water is at subsurface during the period of isopycnal shoaling (Fig. 5), its influence on SST is also noticeable, with the surface remaining $\sim 1.5^{\circ} \mathrm{C}$ cooler than the surrounding gulf.

The blue whale specializes on krill and dominated the cetacean biomass during these 2 periods of surface and subsurface chl a peaks, suggesting those were suitable conditions for low trophic level prey. It is also the only migratory cetacean among all of the species recorded that feeds actively during its wintering period in the gulf (Del-Ángel-Rodríguez 1997, Gendron 2002, Bailey et al. 2009). Variations of its seasonal migration may be responses to a larger scale of interannual oceanic conditions in a manner that is still unstudied. At the seasonal and intraseasonal scales, however, it seems that the distribution of the species within the gulf is guided by the persistence of local pulses of biological production (Pardo et al. 2011) that aggregate krill (Gendron 1992). In one of its major feeding grounds off California, the blue whale abundance also increases in response to the aggregation of krill resulting from the upwelling pulses of the California Current (Croll et al. 2005). In contrast, the migratory humpback whale has been recorded only sporadically feeding on krill within the gulf (Gendron \& Urbán 1993), and its occurrence is more associated with breeding activities during winter. Although krill may also serve as prey for fin and Bryde's whales during the winter and spring within the bay, these species can also exploit juvenile stages of Pacific sardine that aggregate along the western coast of the gulf during this period (Hammann et al. 1988, Tershy 1992, Tershy et al. 1993, Gendron et al. 2001, Jaume-Schinkel 2004) and thus reduce competition with blue whales. Small pelagic fish are also the most likely prey for common dolphins (Gallo-Reynoso 1991, Niño-Torres et al. 2006), which exploit the bay in large numbers during winter. The higher biomasses of bottlenose dolphins over the entire isopycnal shoaling period (May to August) may reflect the availability of mesopelagic fish and/or squid, which are likely prey for this opportunistic species (Pauly et al. 1998, Díaz-Gamboa 2009).

In contrast, the deep stratification of the late summer and autumn was not conducive to high nearsurface nutrient or chl a concentrations. The increase in the proportion of calcareous content in the settling biogenic particles (Fig. 6d) suggests the presence of coccolithophorids, foraminifera, and/or pteropods (Romero et al. 2002). Coccolithophorids are better adapted than silicoflagellates and diatoms to growth at limiting nutrient levels and tend to dominate under oligotrophic conditions (Iglesias-Rodríguez et al. 2002). Nevertheless, despite their dominance, the total flux of coccolithophorids does not increase at all during the late summer in the bay (Rochín-Bañaga 2012), and values of primary production drop (Reyes-Salinas et al. 2003, Cervantes-Duarte et al. 2005). How then might one explain the high peaks of fin and Bryde's whales at this time? The period of high surface water temperatures near the coast frequently marks the spawning season for several pelagic fish species in the southwestern gulf (Moser et al. 1973), including a 'warm stock' of Pacific sardine that enters the gulf (Félix-Uraga et al. 2004). These are likely the main prey for rorqual whales during the deep stratification period, as has been suggested from the $\delta^{15} \mathrm{~N}$ ratios between fin whales and sardines (Jaume-Schinkel 2004). Similarly, the short-finned pilot whale, along with the other teutophagous odontocetes, such as the dwarf sperm whale and the sperm whale (Clarke 1996, Pauly et al. 1998), were in the bay predominately during summer. The maximum biomass peaks of the short-finned pilot whale (August and October 2007; Fig. 8) occurred just when the surface temperature within the bay was the warmest (Fig. 5). Squid searching for warm waters near the coast to spawn typically aggregate under such conditions (Staaf et al. 2008). Thus, we surmise that spawning prey, at least the squid and the Pacific sardine, could sustain the biomass of teutophagous odontocetes and fin whales, respectively, during the deeply stratified summer conditions.

The physical origin of some of the observed watercolumn conditions in the bay is still not fully understood. During winter, Ekman upwelling occurs along the eastern coast of the gulf (Lluch-Cota 2000, Lavín \& Marinone 2003), but most blue whale sightings (Gendron 2002) and large krill aggregations (Brinton \& Townsend 1980) occur on the western side during this period. It is not clear if the series of eddies that form regularly along the gulf (Pegau et al. 2002) could be responsible for cross-gulf transport of nutrients and plankton from east to west, where the material could be retained. Nevertheless, since blooms of siliceous phytoplankton typically occur in response to new nutrient input, it is more likely that the phytoplankton biomass of the southwestern gulf is generated locally due to the strong vertical mixing (Fig. 6a) produced by the northwesterly winds blowing during winter (Fig. 7a). The high surface salinity (>35) observed during this period (Fig. 5) reinforces the hypothesis that strong northwesterly winds lead to a high rate of evaporation, which in turn enhances 
vertical mixing. The causes of the intraseasonal isopycnal shoaling, associated with the second peak in CHL within the bay, are also poorly known. Previous studies have described cyclonic circulation (Monreal-Gómez et al. 2001, Sánchez-Velasco et al. 2006) and proposed that it could be related to the wind curl and the overall seasonal circulation of the gulf (Beier 1997). This CHL peak occurs at a time when the southwesterly wind maximum takes place (Fig. 7a), which could also force the cyclonic circulation and resulting Ekman pumping, but the subject has not been investigated in detail due to the lack of high-resolution data.

Nevertheless, it is clear that the isopycnal shoaling enhances subsurface phytoplankton aggregations within the bay at a time when the rest of the southwestern gulf remains oligotrophic. Therefore, it may also be responsible for the higher annual values of CHL previously described for the bay (Santamariadel-Angel et al. 1994, Luch-Cota \& Teniza-Guillén 2000, Kahru et al. 2004). This phenomenon extends the period of phytoplankton blooms that normally would be associated only with the winter mixing. Recent results of a long-term analysis of blue whale density, comparing La Paz Bay to Loreto Bay, showed that blue whales leave Loreto in April, earlier than their departure from La Paz, where they can be seen as late as June (Pardo et al. 2011). This pattern suggests the importance of the intraseasonal isopycnal shoaling within the bay as a potential driver of krill aggregation in the southwestern gulf at a time when the surroundings are comparatively warmer and oligotrophic (III in Fig. 2).

The presence of cetaceans with different requirements over the course of the year in the bay suggests a sustained availability of prey, aggregated by high biological production or suitable physical conditions. Recent measurements of the proportion of particulate organic carbon in the sinking matter and the monthly fluxes (export production) in the bay (Silverberg 2009, Silverberg et al. 2009) show that these do not vary much seasonally, indicating that biological production extends throughout the year regardless of the type of physical forcing. The export production of the bay is more than double that of Guaymas Basin, often considered a particularly high production area in the gulf (García-Pámanes et al. 2011). All of these characteristics lead us to propose that La Paz Bay constitutes a biological hotspot in the southwestern Gulf of California, driven by the seasonal evolution of regional surface mixing conditions in winter, local isopycnal shoaling in spring and early summer, and deep stratification in late summer and autumn. This physical contrast attracts a wide variety of cetaceans foraging at different trophic levels at different times of the year and probably also favors the incursion of other species of marine megafauna.

Future work should focus on addressing the inferences drawn in the present study regarding the physical and biological mechanisms that drive cetacean occurrence in the bay. Such work would require a sampling grid aimed at resolving spatial patterns in environmental variables concurrently with measurements of the low, mid, and high trophic levels. Testing these mechanistic linkages would require a numerical modeling approach. Two species that would be particularly amenable for such work are the blue whale and the short-finned pilot whale because of their specialist diet and because they showed the most evident relationships with the environment, with blue whales using the bay during periods of cool temperature, high $\mathrm{CHL}$, and a primary producer community dominated by siliceous phytoplankton, while short-finned pilot whales occurred during warm, oligotrophic periods dominated by calcareous phytoplankton. The physical mechanisms driving isopycnal shoaling in the bay during spring and early summer, which make this area biologically richer than the surrounding gulf, should be investigated through a study of the effects of the wind field in combination with the local physiography (as shown by Wingfield et al. 2011). The role of the northwesterly winds in the evaporation and subsequent mixing of the surface layer during winter should be studied to understand the reasons for the aggregation of krill and blue whales along the western coast of the gulf rather than along the upwellinginfluenced eastern coast.

Acknowledgements. The present study received financial support from the Consejo Nacional de Ciencia y Tecnología (CONACyT) through the projects Monitoreo ecológico contínuo de la Bahía de La Paz: Serie de tiempo (47310-F; PI: N.S.) and Investigaciones Oceanográficas del Sistema Frontal de Baja California (SEP-2008-103898; PI: E.B.), as well as MSc and PhD scholarships to M.A.P. The Instituto Politécnico Nacional (IPN) funded part of the field work through the projects Monitoreo Ecológico Continuo en Bahía de La Paz (SIP 20040095, 2005-0274, 20060199, 20070664，20080650，20090523; PI: N.S.) and Estructura poblacional y movimiento de algunos cetáceos del Golfo de California (SIP 20070803; PI: D.G.). D.M.P. was supported by funding from the NASA Applied Sciences Program, Earth Science Division, through a grant provided by Research Announcement NNH07ZDA001N, Research Opportunities in Space and Earth Sciences (ROSES-2007), Program Element A.20: Decision Support through Earth Science Research Results. M.A.P. also received funding from the IPN (PIFI grant), Centro Interdisciplinario de Ciencias Marinas (CICIMAR-IPN; M.Sc. Recovery Funds), The Society for 
Marine Mammalogy (Grants in Aid of Research 2009), Cetacean Society International, American Cetacean Society (Monterey Bay Grant 2008), and The Ocean Foundation. We are grateful to all of the personnel from Laboratorio de Ecología de Cetáceos y Quelonios and Departamento de Oceanología at CICIMAR-IPN for their support during environmental and cetacean sampling. We also thank NOAA CoastWatch Program, NASA's Goddard Space Flight Center, and GeoEye for making the satellite data products readily available. Valuable comments during the study were provided by R. Palomares, G. De-La-Cruz-Agüero, O. Victorivich, R. Díaz-Gamboa, G. Busquets-Vass, and A. MartínezLópez from CICIMAR-IPN.

\section{LITERATURE CITED}

Adams DK, Comrie AC (1997) The North American monsoon. Bull Am Meteorol Soc 78:2197-2213

Álvarez-Gómez IG (2010) Reconstrucción de la variabilidad del clima a través de los silicoflagelados conservados en los sedimentos laminados de Cuenca Alfonso. MSc thesis, Instituto Politécnico Nacional, La Paz, available at www.biblioteca.cicimar.ipn.mx/oacis/ tesisdesplegardetalles.php?id=577

$\mathrm{Au}$ DWK, Perryman WL (1985) Dolphin habitats in the eastern tropical Pacific. Fish Bull 83:623-643

Badan-Dangon A, Dorman CE, Merrifield MA, Winant CD (1991) The lower atmosphere over the Gulf of California. J Geophys Res 96:16877-16896

Bailey H, Mate BR, Palacios DM, Irvine L, Bograd SJ, Costa DP (2009) Behavioural estimation of blue whale movements in the Northeast Pacific from state-space model analysis of satellite tracks. Endang Species Res 10:93-106

Barlow J, Forney KA (2007) Abundance and population density of cetaceans in the California Current ecosystem. Fish Bull 105:509-526

Barlow J, Kahru M, Mitchell BG (2008) Cetacean biomass, prey consumption, and primary production requirements in the California Current ecosystem. Mar Ecol Prog Ser 371:285-295

Becker EA, Forney KA, Ferguson MC, Foley DG, Smith RC, Barlow J, Redfern JV (2010) Comparing California Current cetacean-habitat models developed using in situ and remotely sensed sea surface temperature data. Mar Ecol Prog Ser 413:163-183

Becker EA, Foley DG, Forney KA, Barlow J, Redfern JV, Gentemann CL (2012) Forecasting cetacean abundance patterns to enhance management decisions. Endang Species Res 16:97-112

Beier E (1997) A numerical investigation of the annual variability in the Gulf of California. J Phys Oceanogr 27: 615-632

Bishop JKB (1988) The barite-opal-organic carbon association in oceanic particulate matter. Nature 332:341-343

Bordoni S, Ciesielski PE, Johnson RH, McNoldy BD, Stevens B (2004) The low-level circulation of the North American Monsoon as revealed by QuikSCAT. Geophys Res Lett 31:L10109, doi:10.1029/2004GL020009

Boyer T, Levitus S, Garcia H, Locarnini RA, Stephens C, Antonov J (2005) Objective analyses of annual, seasonal, and monthly temperature and salinity for the World Ocean on a $0.25^{\circ}$ grid. Int J Climatol 25:931-945

Brinton E, Townsend AW (1980) Euphausiids in the Gulf of California: the 1957 cruises. Calif Coop Ocean Fish Invest Rep 21:211-236

Buckland ST, Anderson DR, Burnham KP, Laake JL, Borchers
DL, Thomas L (2001) Introduction to distance sampling. Oxford University Press, Oxford

Burnham KP, Anderson DR (2002) Model selection and multimodel inference, 2nd edn. Springer, New York, NY

Bustillos-Guzmán J, Lechuga-Devéze CH (1989) Secchi disk lectures and scalar quanta irradiance relationships in the Pacific coast off Baja California and Gulf of California. Cienc Mar 15:39-45

> Casey KS, Cornillon P (1999) A comparison of satellite and in situ-based sea surface temperature climatologies. J Clim 12:1848-1863

Cervantes-Duarte R, Verdugo-Díaz G, Váldez-Holguín JE (2005) Modelo estacional de producción primaria estimada mediante fluorescencia natural en una región costera del Golfo de California, México. Hidrobiológica 15:79-87

Clark E, Nelson DR (1997) Young whale sharks, Rhincodon typus, feeding on a copepod bloom near La Paz, Mexico. Environ Biol Fishes 50:63-73

Clarke MR (1996) Cephalopods as prey. III. Cetaceans. Philos Trans R Soc Lond B 351:1053-1065

> Croll DA, Marinovic B, Benson S, Chavez FP, Black N, Ternullo R, Tershy BR (2005) From wind to whales: trophic links in a coastal upwelling system. Mar Ecol Prog Ser 289:117-130

Croll DA, Newton KM, Weng K, Galván-Magaña F, O'Sullivan J, Dewar H (2012) Movement and habitat use by the spine-tail devil ray in the Eastern Pacific Ocean. Mar Ecol Prog Ser 465:193-200

Davis RE (1978) Predictability of sea level pressure anomalies over the North Pacific Ocean. J Phys Oceanogr 8: 233-246

Dawson S, Wade P, Slooten E, Barlow J (2008) Design and field methods for sighting surveys of cetaceans in coastal and riverine habitats. Mammal Rev 38:19-49

Del-Ángel-Rodríguez JA (1997) Hábitos alimentarios y distribución espacio-temporal de los rorcuales común (Balaenoptera physalus) y azul (Balaenoptera musculus) en la Bahía de La Paz, B.C.S., México. MSc thesis, Instituto Politécnico Nacional, La Paz, available at www.cicimar. ipn.mx/oacis/productividad.php?id=1621\&anio=1997\&tipo $=5 \&$ encabezado=Tesis $\% 20$ dirigidas

Díaz-Gamboa RE (2009) Relaciones tróficas de los cetáceos teutófagos con el calamar gigante Dosidicus gigas en el Golfo de California. PhD thesis, Instituto Politécnico Nacional, La Paz, available at www.cicimar.ipn.mx/ oacis/productividad.php?id=3100\&anio $=2009 \&$ tipo $=5 \&$ encabezado=Tesis \%20dirigidas

Domeier ML, Nasby-Lucas N, Palacios DM (2012) The northeastern Pacific white shark shared offshore foraging area (SOFA): a first examination and description from ship observations and remote sensing. In: Domeier ML (ed) Global perspectives on the biology and life history of the white shark. CRC Press, Boca Raton, FL, p 147-158

Doniol-Valcroze T, Berteaux D, Larouche P, Sears R (2007) Influence of thermal fronts on habitat selection by four rorqual whale species in the Gulf of St. Lawrence. Mar Ecol Prog Ser 335:207-216

> Egge JK, Aksnes DL (1992) Silicate as regulating nutrient in phytoplankton competition. Mar Ecol Prog Ser 83:281-289

Emery WJ, Thomson E (1998) Data analysis methods in physical oceanography. Elsevier, Amsterdam

Félix-Uraga R, Gómez-Muñoz VM, Quiñonez-Velázquez C, Melo-Barrera FN, García-Franco W (2004) On the existence of Pacific sardine groups off the west coast of Baja California and southern California. Calif Coop Ocean Fish Invest Rep 45:146-151 
Flores-Ramírez S, Urbán RJ, Villarreal-Chávez G, VallesJiménez R (1996) Spatial and temporal changes in the cetacean community structure at Bahía de La Paz, B.C.S., Mexico (1988-1991). Cienc Mar 22:151-173

- Forney KA, Ferguson MC, Becker EA, Fiedler PC and others (2012) Habitat-based spatial models of cetacean density in the eastern Pacific Ocean. Endang Species Res 16: 113-133

Freilich MH (2000) SeaWinds: algorithm theoretical basis document. NASA, Washington, DC, available at http:// eospso.gsfc.nasa.gov/eos_homepage/for_scientists/atbd/ viewInstrument.php?instrument $=15$

Gallo-Reynoso JP (1991) Group behavior of common dolphins (Delphinus delphis) during prey capture. An Inst Biol Univ Nac Auton Mex Zool 62:253-262

> García-Pámanes J, Trasviña-Castro A, Lara-Lara JR, BazánGuzmán C (2011) Seasonal variability of the particulate organic matter vertical flux in the central region of the Gulf of California. Cienc Mar 37:33-49

Gendron D (1992) Population structure of daytime surface swarms of Nyctiphanes simplex (Crustacea: Euphausiacea) in the Gulf of California, Mexico. Mar Ecol Prog Ser 87:1-6

Gendron D (2002) Ecología poblacional de la ballena azul Balaenoptera musculus de la Península de Baja California. PhD thesis, Centro de Investigación Científica y de Educación Superior de Ensenada, Ensenada, available at http://biblioteca.cicese.mx/catalogo/tesis/ficha.php?id= 15272

Gendron D, Urbán J (1993) Evidence of feeding by humpback whales (Megaptera novaeangliae) in the Baja California breeding ground, Mexico. Mar Mamm Sci 9:76-81

Gendron D, Aguíñiga S, Carriquiry JD (2001) $\delta^{15} \mathrm{~N}$ and $\delta^{13} \mathrm{C}$ in skin biopsy samples: a note on their applicability for examining the relative trophic level in three rorqual species. J Cetacean Res Manag 3:41-44

Gerrodette T, Eguchi T (2011) Precautionary design of a marine protected area based on a habitat model. Endang Species Res 15:159-166

Hamazaki T (2002) Spatiotemporal prediction models of cetacean habitats in the mid-western North Atlantic Ocean (from Cape Hatteras, North Carolina, U.S.A. to Nova Scotia, Canada). Mar Mamm Sci 18:920-939

Hammann MG, Baumgartner TR, Badan-Dangon A (1988) Coupling of the Pacific sardine (Sardinops sagax caeruleus) life cycle with the Gulf of California pelagic environment. Calif Coop Ocean Fish Invest Rep 29:102-109

Hooker SB, McClain CR (2000) The calibration and validation of SeaWiFS data. Prog Oceanogr 45:427-465

> Iglesias-Rodríguez MD, Brown CW, Doney SC, Kleypas J and others (2002) Representing key phytoplankton functional groups in ocean carbon cycle models: coccolithophorids. Global Biogeochem Cycles 16:1100, doi:10.1029/ 2001GB001454

Jalickee JB, Hamilton DR (1977) Objective analysis and classification of oceanographic data. Tellus 29:545-560

Jaume-Schinkel MS (2004) Hábitos alimentarios del rorcual común Balaenoptera physalus en el Golfo de California mediante el uso de isótopos estables de nitrógeno y carbono. MSc thesis, Instituto Politécnico Nacional, La Paz, available at www.cicimar.ipn.mx/oacis/productividad. php?id=1729\&anio=2004\&tipo=5\&encabezado=Tesis $\% 20$ dirigidas

Kahru M, Marinone SG, Lluch-Cota SE, Parés-Sierra A, Greg Mitchell B (2004) Ocean-color variability in the Gulf of California: scales from days to ENSO. Deep-Sea Res II 51:139-146
Ketchum-Mejía JT (2003) Distribución espacio-temporal y ecología alimentaria del tiburón ballena (Rhincodon typus) en la Bahía de La Paz y zonas adyacentes en el suroeste del Golfo de California. MSc thesis, Instituto Politécnico Nacional, La Paz, available at www.cicimar. ipn.mx/oacis/productividad.php?id=1734\&anio $=2003 \&$ tipo $=5 \&$ encabezado $=$ Tesis $\% 20$ dirigidas

Kilpatrick KA, Podestá GP, Evans R (2001) Overview of the NOAA/NASA advanced very high resolution radiometer Pathfinder algorithm for sea surface temperature and associated matchup database. J Geophys Res 106: 9179-9197

- Kudela RM, Banas NS, Barth JA, Frame ER and others (2008) New insights into the controls and mechanisms of plankton productivity in coastal upwelling waters of the northern California Current System. Oceanography (Wash DC) 21:46-59

Lavín MF, Marinone SG (2003) An overview of the physical oceanography of the Gulf of California. In: VelascoFuentes OU, Sheinbaum J, Ochoa J (eds) Nonlinear processes in geophysical fluid dynamics. Kluwer, Dordrecht, p 173-204

> Lerczak JA, Hobbs RC (1998) Calculating sighting distances from angular readings during shipboard, aerial, and shore-based marine mammal surveys. Mar Mamm Sci 14:590-599

Lluch-Cota SE (2000) Coastal upwelling in the eastern Gulf of California. Oceanol Acta 23:731-740

Luch-Cota DB, Teniza-Guillén G (2000) BAC versus áreas adyacentes de la variabilidad interanual de pigmentos fotosintéticos a partir del Coastal Zone Color Scanner (CZCS). In: Lluch-Belda D, Elorduy-Garay J, Lluch-Cota SE, Ponce-Díaz G (eds) BAC, centros de actividad biológica del Pacífico mexicano, 1st edn. Centro de investigaciones Biológicas del Noroeste, S.C., La Paz, p 198-218

Martínez-López A, Álvarez-Gómez IG, Durazo R (2012) Climate variability and silicoflagellate fluxes in Alfonso Basin (southern Gulf of California). Bot Mar 55:1-9

- Monreal-Gómez MA, Molina-Cruz A, Salas-de-León DA (2001) Water masses and cyclonic circulation in Bay of La Paz, Gulf of California, during June 1998. J Mar Syst 30:305-315

Moser HG, Ahlstrom EH, Kramer D, Stevens EG (1973) Distribution and abundance of fish eggs and larvae in the Gulf of California. Calif Coop Ocean Fish Invest Rep XVII:112-128

Niño-Torres CA, Gallo-Reynoso JP, Galván-Magaña F, Escobar-Briones E, Macko SA (2006) Isotopic analysis of $\delta^{13} \mathrm{C}, \delta^{15} \mathrm{~N}$, and $\delta^{34} \mathrm{~S}$ 'A feeding tale' in teeth of the longbeaked common dolphin, Delphinus capensis. Mar Mamm Sci 22:831-846

O'Reilly JE, Maritorena S, Mitchell BG, Siegel DA and others (1998) Ocean color chlorophyll algorithms for SeaWiFS. J Geophys Res 103:24937-24953

O'Reilly JE, Maritorena S, Siegel DA, O'Brien MC and others (2000) Ocean color chlorophyll a algorithms for SeaWiFS, OC2 and OC4: version 4. In: Hooker SB, Firestone ER (eds) SeaWiFS postlaunch calibration and validation analyses, Part 3. NASA Tech Memo 206892, Vol 11, p 9-23

Obeso-Nieblas M, Shirasago B, Sanchez-Velasco L, GaviñoRodriguez JH (2004) Hydrographic variability in Bahia De La Paz, B.C.S., Mexico, during the 1997-1998 El Niño. Deep-Sea Res II 51:689-710

Palacios DM, Bograd SJ, Foley DG, Schwing FB (2006) Oceanographic characteristics of biological hot spots in 
the North Pacific: a remote sensing perspective. DeepSea Res II 53:250-269

Pardo MA, Gendron D, Beier E (2011) Seasonal habitat variability for the blue whale in the southwestern Gulf of California: implications for the species' conservation. Conservation Science Symposium, Species of Concern, Loreto, 25-27 May 2011, p 8-9, available at http://conservationscience.com.mx/abstracts.html (Abstract)

Pauly D, Trites AW, Capuli E, Christensen V (1998) Diet composition and trophic levels of marine mammals. ICES J Mar Sci 55:467-481

Pegau WS, Boss E, Martínez A (2002) Ocean color observations of eddies during the summer in the Gulf of California. Geophys Res Lett 29, doi:10.1029/2001GL014076

Praca E, Gannier A, Das K, Laran S (2009) Modelling the habitat suitability of cetaceans: example of the sperm whale in the northwestern Mediterranean Sea. DeepSea Res I 56:648-657

Reyes-Salinas A, Cervantes-Duarte R, Morales-Pérez RA, Valdez-Holguín JE (2003) Variabilidad estacional de la productividad primaria y su relación con la estratificación vertical en la Bahía de la Paz, B.C.S. Hidrobiológica 13:103-110

Ripa P (2002) Least squares data fitting. Cienc Mar 28: 79-105

Ritchie RJ (2008) Universal chlorophyll equations for estimating chlorophylls $a, b, c$, and $d$ and total chlorophylls in natural assemblages of photosynthetic organisms using acetone, methanol, or ethanol solvents. Photosynthetica 46:115-126

Rochín-Bañaga H (2012) Aporte de carbonato de calcio en Cuenca Alfonso mediante el flujo de nanopláncton calcáreo. BSc thesis, Universidad Autónoma de Baja California Sur, La Paz

Romero O, Boeckel B, Donner B, Lavik G, Fischer G, Wefer G (2002) Seasonal productivity dynamics in the pelagic central Benguela System inferred from the flux of carbonate and silicate organisms. J Mar Syst 37:259-278

Salinas-González F, Zaytsev O, Makarov V (2003) Formation of the thermohaline structure of water in the Bahía de La Paz from summer to autumn. Cienc Mar 29:51-65

Salvadeo CJ, Gómez-Gallardo A, Lluch-Belda D, Urbán RJ (2009) The odontocete community and its environment in the southwestern Gulf of California. Lat Am J Aquat Mamm 7:23-32

Sánchez-Velasco L, Beier E, Avalos-García C, Lavín MF (2006) Larval fish assemblages and geostrophic circulation in Bahía de La Paz and the surrounding southwestern region of the Gulf of California. J Plankton Res 28: 1081-1098

Santamaria-del-Angel E, Alvarez-Borrego S, Muller-Karger FE (1994) Gulf of California biogeographic regions based on coastal zone color scanner imagery. J Geophys Res 99: 7411-7421

Silver MW, Gowing MM (1991) The 'particle' flux: origins and biological components. Prog Oceanogr 26:75-113

Silverberg N (2009) Vistazo sobre la producción exportada de carbono orgánico particulado en las áreas marinas de México. In: Primer Simposio Internacional del Carbono en Mexico. INE - PMC, Ensenada

Silverberg N, Aguirre F, Aguíniga S, Romero N (2006) Vertical flux of particulate matter in Alfonso Basin, La Paz Bay, during 2002. Cienc Mar 32:73-82

Silverberg N, Aguirre-Bahena F, Zaytsev O (2009) Últimos resultados sobre la materia en hundimiento en Cuenca
Alfonso, Bahía de La Paz: Serie de tiempo 2002-2009. In: Reunión Anual de la Unión Geofísica Mexicana - Sesión Especial: Acoplamiento bio-oceanográfico en la Bahía de La Paz y región sur del Golfo de California. Unión Geofísica Mexicana, Puerto Vallarta, p 122, available at www.ugm.org.mx/publicaciones/geos/index.php?page= publicaciones-2009-i

Staaf DJ, Camarillo-Coop S, Haddock SHD, Nyack AC and others (2008) Natural egg mass deposition by the Humboldt squid (Dosidicus gigas) in the Gulf of California and characteristics of hatchlings and paralarvae. J Mar Biol Assoc UK 88:759-770

Strickland JDH, Parsons TR (1972) A practical handbook of seawater analysis, 2nd edn. Bull Fish Res Board Can 167: $1-310$

Szteren D, Aurioles D, Gerber LR (2006) Population status and trends of the California sea lion (Zalophus californianus californianus) in the Gulf of California, Mexico. In: Trites A, Atkinson S, DeMaster D, Fritz L, Gelatt T, Rea L, Wynne K (eds) Sea lions of the world. Alaska Sea Grant College Program/University of Alaska Fairbanks, Fairbanks, AK, p 369-384

Tershy BR (1992) Body size, diet, habitat use, and social behavior of Balaenoptera whales in the Gulf of California. J Mammal 73:477-486

Tershy BR, Acevedo-G A, Breese D, Strong CS (1993) Diet and feeding behavior of fin and Bryde's whales in the central Gulf of California, Mexico. Rev Invest Cient Univ Auton Baja Calif Sur 1:1-4 (Ser Cienc Mar)

Thomas L, Buckland ST, Burnham KP, Anderson DR, Laake JL, Borchers DL, Strindberg S (2002) Distance sampling. In: El-Shaarawi AH, Piegorsch WW (eds) Encyclopedia of environmetrics. John Wiley \& Sons, Chichester, p 544-552

Trites AW, Christensen V, Pauly D (1997) Competition between fisheries and marine mammals for prey and primary production in the Pacific Ocean. J Northwest Atl Fish Sci 22:173-187

Verdugo-Díaz G (2003) Respuesta ecofisiológica del fitoplancton ante la variabilidad ambiental en una laguna costera sub-tropical de Baja California Sur, México. PhD thesis, Instituto Politécnico Nacional, La Paz

Villegas-Aguilera MM (2009) Fitoplancton silíceo de la zona eufótica, como señal de la productividad primaria en Cuenca Alfonso, Golfo de California. MSc thesis, Instituto Politécnico Nacional, La Paz, available at www. cicimar.ipn.mx/oacis/productividad.php?id=3155\&anio= 2009\&tipo $=5 \&$ encabezado $=$ Tesis $\% 20$ dirigidas

> Wahl RJ, Teague WJ (1983) Estimation of Brunt-Väisälä frequency from temperature profiles. J Phys Oceanogr 13: 2236-2240

> Walker TA (1982) Use of a Secchi disc to measure attenuation of underwater light for photosynthesis. J Appl Ecol 19:539-544

Walton CC, Pichel WG, Sapper JF, May DA (1998) The development and operational application of nonlinear algorithms for the measurement of sea surface temperatures with the NOAA polar-orbiting environmental satellites. J Geophys Res 103:27999-28012

Williams R, Thomas L (2007) Distribution and abundance of marine mammals in the coastal waters of British Columbia, Canada. J Cetacean Res Manag 9:15-28

> Wingfield DK, Peckham SH, Foley DG, Palacios DM and others (2011) The making of a productivity hotspot in the coastal ocean. PLoS ONE 6:e27874 